\title{
IMPROVEMENTS IN QUANTIFICATION OF BIOMASS FEEDSTOCK AVAILABILITY TO A BIOREFINERY USING A GIS-BASED METHOD
}

\author{
A. Martinez, D. E. Maier
}

\begin{abstract}
The feasibility of utilizing cellulosic biomass such as corn stover as an energy feedstock is dominated by factors such as facility location, feedstock availability, and transportation cost. Previous research showed the advantages of using a GIS-based method compared to a previously used concentric ring buffer method. Even though the GIS-based method proved to be more accurate because it precisely calculates the distance from the facility to the farms using a real road network and the hectares of crop-specific fields in a given service area, opportunities exist to further improve its accuracy. In this case study, two improvement parameters were implemented to the previously proposed GIS-based method to examine the effect of field-level yield variance and variable residue removal rates on the quantification of feedstock availability for a biorefinery. The new variable residue removal (VRR) method predicted on average 113,384 $\pm 38,770$ dry tons (DT) of additional residue per service area compared to the previous constant residue removal (CRR) method. The use of a constant removal rate of $3 D T$ ac ${ }^{-1}$ in the CRR method clearly underestimated feedstock availability, given that residue removal rates are highly variable and subject to location, erosive forces, soil characteristics, crop type, yield, and field management. However, to prevent soil erosion and maintain soil productivity, conservation tillage practices require that at least $30 \%$ of the soil surface must be covered with residue after planting the next crop. Even with a reduction in total feedstock availability, the VRR method estimated comparable residue availability per service area to the CRR meth$o d$, with only a $4 \pm 6 \%$ decrease per service area on average. Consequently, the VRR method turned out to be the preferred approach in the quantification of biomass feedstock availability.
\end{abstract}

Keywords. Biomass, Feedstock availability, Geospatial image system (GIS), Transportation logistics.

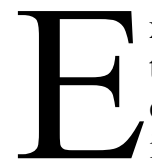
xtensive research is ongoing to evaluate the potential of various renewable feedstocks for efficient conversion into biofuel. One challenge lies in strategically locating biomass conversion facilities in order to supply them with feedstock in an economically feasible manner. The logistics challenge is dominated by factors such as facility location, feedstock availability, and transportation cost.

A feedstock's dispersed spatial availability and seasonal availability are among the challenges associated with the optimized selection of a facility's location and the quantification of feedstock availability. These challenges are also known to significantly contribute to feedstock transportation costs, as reported in the Biomass Road Map (USDA, 2003) and several recent studies (De Mol et al., 1997; Sokhansanj and Turhollow, 2002; Ravula et al., 2003; Cundiff et al., 2004; Krishnakumar and Ileleji, 2010). Ultimately,

Submitted for review in March 2013 as manuscript number FPE 10171; approved for publication by the Food \& Process Engineering Institute of ASABE in February 2014. Presented at the 2012 ASABE Annual Meeting as Paper No. 121336807.

The authors are Adrian Martinez, ASABE Member, Graduate Student, and Dirk E. Maier, ASABE Member, Professor and Head, Department of Grain Science and Industry, Kansas State University, Manhattan, Kansas. Corresponding author: Dirk E. Maier, 201 Shellenberger Hall, Kansas State University, Manhattan, KS 66506; phone: 785-532-4052; e-mail: dmaier@ksu.edu. correct facility location selection will result in more precisely quantifying feedstock availability and predicting transportation costs.

Martinez and Maier (2011) proposed a Geographical Information System (GIS) based approach for quantifying feedstock availability that utilized a real road network and geo-referenced, crop-specific satellite images. The intent was to compare this new approach to a previous approach proposed by Mukunda et al. (2006), which quantified hectare availability using concentric ring buffers together with the USDA Census of Agriculture data (USDA, 2002). The GIS-based method proposed by Martinez and Maier (2011) estimated hectare availability using satellite images from which a service area was created based on a map-based road network dataset. It was concluded that the GIS-based method was more reliable compared to Mukunda et al. (2006) due to more precise service area calculation and better estimation of hectare availability per service area. While the proposed GIS-based method proved feasible, the next logical step was to improve its capability of quantifying feedstock availability.

The main goal of this case study was to improve the previously proposed GIS-based feedstock sourcing method and to utilize the improved approach to predict corn stover availability for a Kansas-based biomass conversion facility. 


\section{IMPROVEMENT PARAMETERS}

Estimating variable residue removal rates, rather than using a constant removal rate, was needed to improve the quantification of feedstock availability. To be able to estimate variable residue removal rates, field-level yield estimations were needed. Consequently, the effects of fieldlevel yield variance (based on soil characteristics) and variable residue removal rates (based on erosion, soil characteristics, yield, and field management) were examined as improvement parameters.

\section{Field-Level Yield Variance}

The first improvement parameter examined was the effect of field-level yield variance based on soil characteristics. Crop fields are generally composed of different soil map units (i.e., soil types), as shown in figure 1. Soil map unit delineation on a soil map represents an area dominated by one or more major kinds of soils. Soil map units are identified and named according to the taxonomic classification of the dominant soils. Areas of soil of a single taxonomic class can rarely be mapped without including areas of other taxonomic classes. Consequently, every map unit is made up of the soils for which it is named as well as some minor components that belong to taxonomic classes other than those of the major soils. Most minor soils have properties similar to those of the dominant soils or soils in the map unit, and thus they are assumed to not affect land use or management.

Soil maps are available from the USDA National Resource Conservation Service (NRCS). The two most used databases are the State Soil Geographic (STATSGO) and the Soil Survey Geographic (SSURGO). The SSURGO database provides the most detailed level of information and serves as an excellent source for determining erodible areas and developing erosion control practices. Among the information available in the SSURGO database are soilbased parameters such as yield, hectare extent, erodibility factors, tolerable soil loss, and percent slope. The NRCS makes these data available in both tabular and spatial form.

\section{Variable Residue Removal Rates}

The second improvement parameter examined was variable residue removal rates. The key factors affecting residue removal rates are erosion, soil characteristics, yield, and field management. In the previously proposed GISbased method, $100 \%$ of the corn stover residue was removed at a constant removal rate of 7.4 dry tons (DT) ha ${ }^{-1}$ $\left(3 \mathrm{DT} \mathrm{ac}^{-1}\right)$ throughout the study area. This is not common practice, given that removing all the residue from a field will lead to erosion problems and loss in soil productivity due to the lack of nutrient cycling, among other factors. Therefore, to be able to more accurately estimate agricultural crop residue removal, variable residue removal rates were examined in detail with respect to erosion, soil characteristics, field-level crop yield, and field management using the USDA Wind Erosion Prediction System (WEPS; USDA, 2012a). This simulation software was chosen because, according to the NRCS National Resource Inventory (NRI), in a typical year wind erosion predominates over water erosion in our selected study area (fig. 2).

\section{SENSITIVITY ANALYSIS OF SSURGO DATA}

A sensitivity analysis was performed on the SSURGO data to collect preliminary data, given that not all soil yields were present in the data acquired from the NRCS. This analysis was deemed necessary because if a soil yield was not present, then the hectares of that soil would not be taken into account when calculating hectare-weighted yields (HWYlds). HWYlds are the result of dividing total crop production, which is calculated by multiplying yield and soil hectares, by total soil hectares and are used to estimate field-level yields and variable residue removal rates. Consequently, the purpose of this sensitivity analysis was to quantify the effect of replacing "no data" yield values with an average yield.

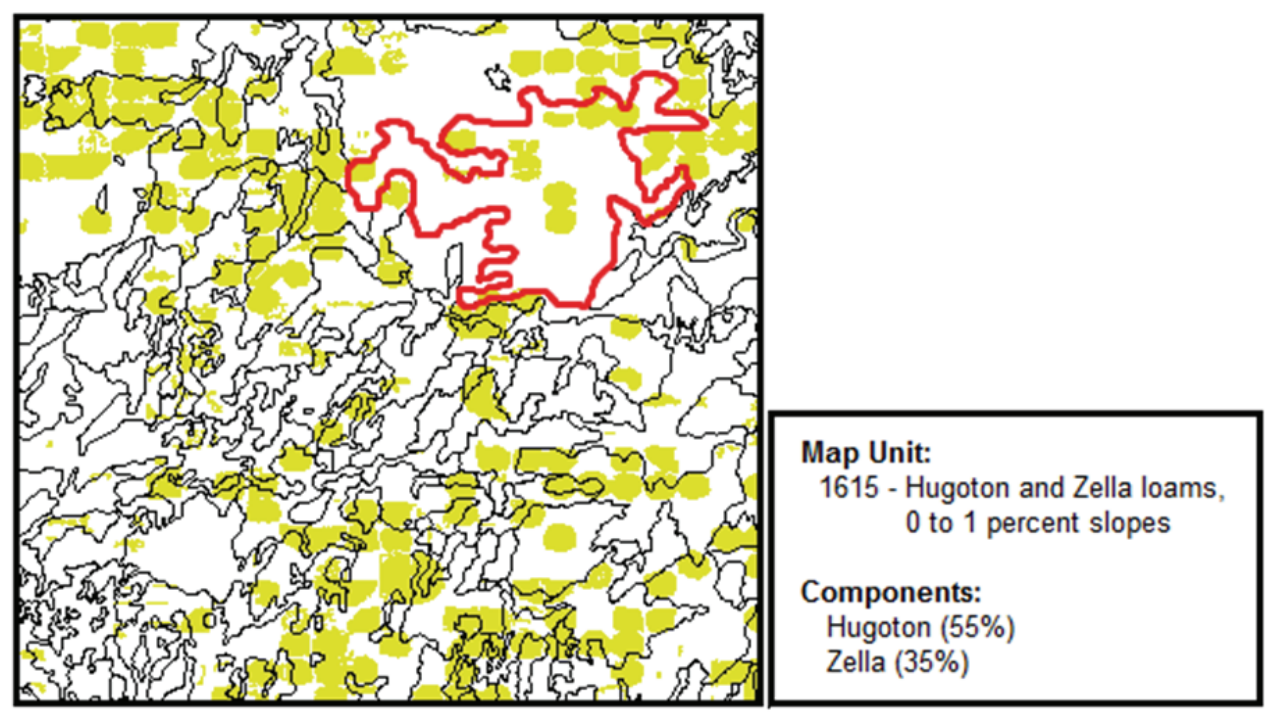

Figure 1. Overlay of the corn data layer showing the corn fields (yellow) and the soil layer showing the different soil map units (polygons) available in the northeastern part of Stevens County, Kansas. The legend identifies the soil map unit, taxonomic classification, and percent composition of the highlighted (red) polygon. 


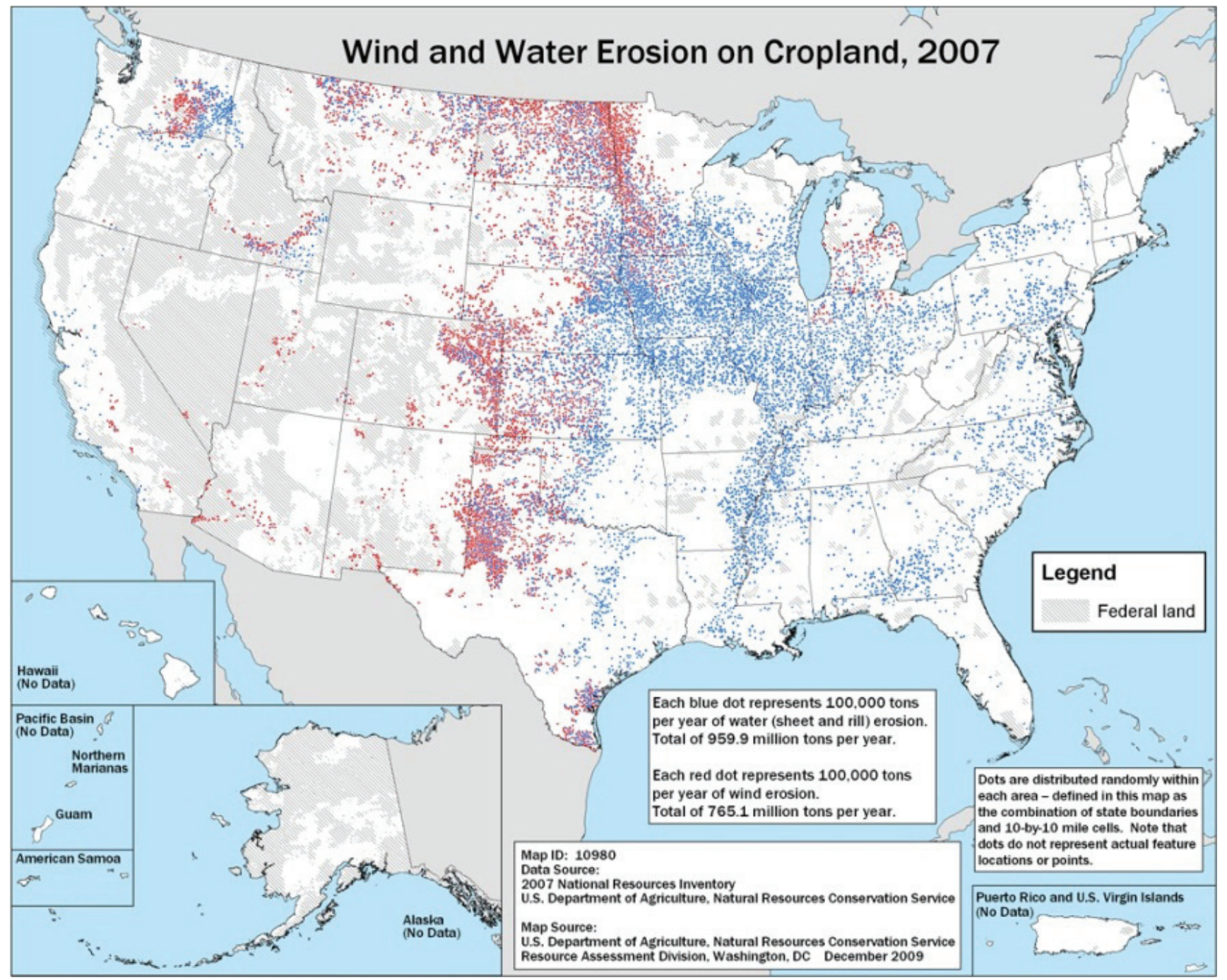

Figure 2. Twenty-five year estimate (1982 to 2007) of wind (red dots) and water (blue dots) erosion on cropland from the National Resource Inventory (NRI) 2007 survey of soil erosion on cropland (USDA, 2007).

\section{LITERATURE REVIEW}

GIS software has been used by researchers to predict feedstock supply areas for existing and planned biomassbased processing facilities. Accurately predicting a feedstock supply area will help to locate conversion facilities and supply them with biomass in an economically feasible manner. A review of the literature regarding factors that affect field-level yields as well as residue removal rates was done, given that this case study focuses on these improvement parameters.

Agricultural residue removal rates are highly variable and depend on factors such as crop type, yield, location, soil characteristics, and field management, among other factors. Despite the high variability of residue removal, constant residue removal rates, based on hectare availability, are typically used in case studies that estimate feedstock availability. A constant residue removal rate of 7.4 DT ha ${ }^{-1}$ (3 DT ac ${ }^{-1}$ ) has been used to calculate corn stover availability (Perlack and Turhollow, 2003; Mukunda et al., 2006).

Perlack and Turhollow (2003) evaluated the costs for collecting, handling, and hauling corn stover to an ethanol con- version facility. To be able to calculate these costs, several assumptions were made regarding corn stover yield, erosion control, nutrient cycling, corn density, farmers' willingness to sell stover, and location/weather-related inhibiting factors. Corn stover yield was estimated by multiplying corn yield (bu ac ${ }^{-1}$ ), corn grain dry matter content, and stover to grain ratio. For their control scenario, the researchers estimated a constant removal rate of 7.7 DT ha ${ }^{-1}\left(3.1 \mathrm{DT} \mathrm{ac}^{-1}\right)$ based on an average corn yield of $8.27 \mathrm{MT} \mathrm{ha}^{-1}\left(130 \mathrm{bu} \mathrm{ac}^{-1} ; 6.36\right.$ to 10.18 MT ha $^{-1} ; 100$ to $160 \mathrm{bu} \mathrm{ac}^{-1}$ ), corn grain dry matter content of 0.85 , and grain to stover ratio of $1: 1$. It was assumed that only $35 \%$ on average $(20 \%$ to $50 \%)$ of this stover yield could be collected to control erosion and maintain soil nutrients. As a result, stover yield was reduced to $2.7 \mathrm{DT} \mathrm{ha}^{-1}$ $\left(1.1 \mathrm{DT} \mathrm{ac}^{-1}\right)$ from the initial estimates. Corn density, farmers' willingness to sell stover, and location/weather-related inhibiting factors were assumed to be $30 \%, 50 \%$, and $10 \%$, respectively. The collection area was then calculated by assuming a plant capacity (million gallons per year; MGY), a biomass yield of $272.5 \mathrm{~L} \mathrm{DT}^{-1}$ (72 gal DT' $\mathrm{DT}^{-1}$, and the previously estimated corn stover yield. The hauling distance was computed as the radius of the average collection area. Given 
that straight-line distances were measured, a tortuosity factor had to be used to simulate a road network's natural weaving pattern.

Mukunda et al. (2006) developed a discrete event simulation to model the transportation logistics of a corn stover feedstock-based supply system. The feedstock availability input data that were fed into the transportation logistics model were estimated using ArcGIS (ver. 9.3. Redlands, Cal.: ESRI, Inc.) and agricultural statistics. Mukunda et al. (2006) estimated the distance from the facility to the farm fields using $16 \mathrm{~km}$ (10 mi) concentric ring buffers in ArcGIS. Feedstock availability per service area (i.e., each $16 \mathrm{~km}$ ring buffer) was then calculated by multiplying hectare availability, which was estimated from the 2002 Census of Agriculture (USDA, 2002), by a constant removal rate of $7.4 \mathrm{DT} \mathrm{ha}^{-1}\left(3 \mathrm{DT} \mathrm{ac}^{-1}\right)$. Based on observations, two input variables were responsible for most of the loss in accuracy when estimating feedstock availability. First, straight-line distance calculations from the facility to the farm fields were used, requiring a tortuosity factor later on in the transportation logistics model similar to that of Perlack and Turhollow (2003). Nonetheless, it was still not as accurate as a real road network. Second, the agricultural statistics used were county-level based. As a result, when calculating hectare availability per service area, it was assumed that the available hectares were distributed evenly throughout the county, which is rarely seen.

Martinez and Maier (2011) proposed a GIS-based approach that utilized a real road network and geo-referenced, crop-specific satellite images to quantify feedstock availability. Their intent was to compare the new GIS-based method to the method used by Mukunda et al. (2006), as well as to explore its practical application. The proposed method estimated hectare availability using satellite images from which a service area was created based on a map-based road network dataset. Service areas, based on the actual road network, were created every $16 \mathrm{~km}(10 \mathrm{mi})$ from the specified facility location. The cropland data layer (CDL) and service areas were then intersected to generate a layer with corn fields according to service area. This allowed calculation of the corn field hectares in each $16 \mathrm{~km}(10 \mathrm{mi})$ service area. Subsequently, feedstock was quantified using a constant removal rate of $7.4 \mathrm{DT} \mathrm{ha}^{-1}\left(3 \mathrm{DT} \mathrm{ac}^{-1}\right)$. The authors concluded that their proposed method was more reliable compared to Mukunda et al. (2006) in service area calculation and estimation of hectare availability. The more precise service area calculation (by a factor of $1.5 \pm 0.12$ on average) was the result of using a road network dataset instead of concentric circles. The better estimation of hectare availability per service area (by a factor of $1.45 \pm 0.41$ on average) was the result of using field-level satellite images instead of county-level statistics. The one drawback was the use of a constant removal rate of 7.4 DT ha ${ }^{-1}\left(3 \mathrm{DT} \mathrm{ac}^{-1}\right)$ to estimate feedstock availability. Removal rates are highly variable from field to field due to location, erosive forces, soil characteristics, crop type, yield, and field management.

Nelson (2002) developed a methodology to estimate hectare-weighted, county-level corn stover and wheat straw removable quantities subject to rainfall and wind-induced soil erosion. He chose both rainfall and wind erosion because these erosive forces predominate in his selected study area, which consisted of 37 U.S. states. Nelson concluded that of the 37 states analyzed, North Dakota, Nebraska, Kansas, Oklahoma, Texas, and portions of south-central Minnesota and north-central Iowa were predominantly subject to wind erosion. In the other states, rainfall was the dominant erosive force. To estimate the amount of crop residue that could be removed from the field without exceeding tolerable soil loss limits, the amount of residue required for rainfall or wind erosion control (whichever was greater) was subtracted from the amount of corn stover and/or wheat straw residue produced on an annual basis. The amount of residue required for erosion control was estimated using the wind erosion equation (WEQ) and the revised universal soil loss equation (RUSLE). With these equations, the minimum crop yields required to ensure that the average annual soil loss did not exceed the tolerable soil loss limit were calculated.

Another study (Gupta et al., 1979) was found to use WEQ in past analysis to evaluate whether agricultural crop residues could be removed for alternative purposes, such as bioenergy feedstock. The WEQ was the precursor of the WEPS. Nowadays, the WEPS is used to estimate average annual soil erosion on a site-specific field characterized by a particular soil type, slope and runoff length, field length, cropping and management practice, and localized climate.

\section{Materials ANd Methods}

The reference location for this case study was the Abengoa Bioenergy Hybrid of Kansas facility near Hugoton, Kansas. Choosing the same location as Martinez and Maier (2011) helped us quantify the accuracy gained as a result of utilizing field-level yield variance and variable residue removal rates as improvement parameters.

\section{SENSITIVITY ANALYSIS OF SSURGO DATA}

To quantify the effect on field-level yields and variable residue removal rates of replacing "no data" yield values with an average yield, county HWYlds were first calculated for all counties in the study area. Soil data (i.e., land capability class, hectare extent, and yield) for individual counties were first obtained through the NRCS Soil Data Mart (USDA, 2012b). Land capability class (LCC), hectare extent, and yield were then matched using soil map units, a unique soil identifier. County soil data were then sorted by LCC, and then by hectare extent within the LCC. The LCC is a classification based on quality of soil resources for agricultural use. Soils are grouped according to their limitations, among other factors, and are classified into eight categories, with LCC 1 being the best soils and LCC 8 being the poorest. The county HWYld was calculated using only existing SSURGO yields by dividing the total crop production by the total hectares of soils classified LCC 1, 2, 3, and 4. This value was labeled the original county HWYld. A modified county HWYld was calculated in the same manner with "no data" soil yield values, if any, replaced with the corresponding soil average LCC yield. This average 
LCC yield was calculated for each county LCC using only existing SSURGO yields. The counties with the minimum and maximum percent difference between original and modified county HWYlds were selected, as well as eight other counties that fell within that range, to be further analyzed.

\section{IMPROVEMENTS TO THE GIS-BASED METHOD}

Corn hectare availability and service areas were obtained using the GIS-based methodology of Martinez and Maier (2011). In brief, CDL satellite images for crop years 2008 and 2009 were first acquired from the USDA Geospatial Data Gateway (USDA, 2010). The CDL images were then merged, from which corn hectares were extracted. Using the Network Analyst Tool in ArcGIS, service areas were created in $16 \mathrm{~km}(10 \mathrm{mi})$ increments up to $160 \mathrm{~km}$ $(100 \mathrm{mi})$, starting from the selected facility location (Hugoton, Kans.) as the reference point. The methodology was then modified to take into account the two improvement parameters.

The first improvement parameter, field-level yield variance, was estimated using soil data from the SSURGO database. These data were acquired and sorted in the same manner as in the sensitivity analysis. County HWYlds were then calculated with "no data" soil yield values, if any, being replaced with the corresponding soil average LCC yield. These county HWYlds were subsequently validated against a ten-year USDA-NASS county yield average. Once yields were validated, a LCC HWYld was calculated in the same manner using only soils in each LCC. All LCC HWYlds were then joined to a soil LCC thematic map of the study area, which was created in ArcGIS using the NRCS Soil Data Viewer extension (USDA, 2011a).

The second improvement parameter, variable residue removal rates, was estimated using WEPS. Factors such as weather, soil characteristics, yield, and field management were taken into account when running wind erosion simulations for soils classified as LCC 1, 2, 3, or 4 for each county. The soil with the highest hectare extent in each LCC was chosen to represent that LCC. Yields (i.e., LCC HWYlds) were obtained from the first improvement parameter estimates, and field management chosen was one representative for that region (table 1). Other WEPS parameters of importance were "region," "location," and "simulation run." The "region" parameter describes the field geometry for WEPS. Field size was set to 53 ha (130 acres) for all wind erosions, given that center-pivots in southwestern Kansas are typically installed in quarter sections (160 acres) of a square-mile field. The "location" parameter defines the physical location of the field to be sim-

Table 1. Field management used to simulate wind soil erosion.

\begin{tabular}{clc}
\multicolumn{2}{c}{ Table 1. Field management used to simulate wind soil erosion. } \\
\hline Date & & Vegetation \\
\hline (2001) & WEPS Operation & - \\
\hline Apr. 1 & Sprayer, kill crop & - \\
Apr. 20 & Fertilizer, anhydrous w/ knife, 30 in. depth & Corn \\
Apr. 20 & Planter, double-disk opener, fluted coulter & - \\
June 20 & Sprayer, post-emergence & - \\
July 20 & Sprayer, insecticide post-emergence & - \\
Oct. 1 & Harvest, kill crop, 20\% standing stubble & - \\
Oct. 2 & Rake or windrower & - \\
Oct. 5 & Bale straw or residue & - \\
\hline
\end{tabular}

ulated and assists in selecting weather stations. Location varied depending on which county was being simulated. The "simulation run" parameter specifies the WEPS simulation length. The NRCS mode, which specifies a fixed number of rotation cycles or years to be simulated (50 for this study), was chosen for all simulations. Simulations were run for all possible soil types and LLC HWYld combination scenarios and then joined to the soil thematic map created in ArcGIS.

Once both improvement parameters were joined to the soil thematic map, this map was intersected with the corn hectare availability map. The output map was subsequently intersected with the service area polygons to generate ten maps with fields and their corresponding residue removal rates according to service area. This allowed for quantification of the residue in each $16 \mathrm{~km}(10 \mathrm{mi})$ service area. To calculate percent of feedstock per service area, the total dry tonnage required to meet the annual feedstock requirement of a given facility was first calculated using a biomass yield of $272.5 \mathrm{~L} \mathrm{DT}^{-1}\left(72 \mathrm{gal} \mathrm{DT}^{-1}\right)$, as in the previous constant residue removal rate GIS-based method. The residue available per service area was then divided by the estimated annual feedstock requirement, resulting in percent of feedstock per service area for five facility capacities ranging from 151 to 757 million L per year (MLY; 40 to 200 MGY).

\section{VALIDATION OF HECTARE-WEIGHTED YiELdS}

Before the LCC HWYlds were used to estimate variable residue removal rates, the county HWYlds were validated against ten-year NASS irrigated corn yield averages, which were initially cross-checked for accuracy against sevenyear Farm Service Agency (FSA) irrigated corn yield averages. First, the NASS and FSA irrigated corn yields were acquired. County averages were then calculated for each set using the ten (NASS) and seven (FSA) most recent (yearwise) available county yields. A yield range of $\pm 10 \%$ was then calculated for each county using the ten-year NASS irrigated corn yield averages. The seven-year FSA yield averages were then compared against the established range to see if they were within range. Once the NASS yield averages were validated, they were compared against the modified county HWYlds in the same manner.

\section{RESULTS AND DISCUSSION \\ SENSITIVITY ANALYSIS OF SSURGO DATA}

The first two parts of table 2 shows the estimated original and modified HWYlds and estimated residue removal rates per LCC for ten counties in the study area. Using Stevens County as an example, the original LCC 1 HWYld was calculated using only LCC 1 soils that came with a yield in the original SSURGO data. The original HWYld value for LCC 1 was $12.35 \mathrm{MT} \mathrm{ha}^{-1}\left(194 \mathrm{bu} \mathrm{ac}^{-1}\right)$. After the "no data" yield values were replaced with the calculated average LCC 1 yield, the HWYld for LCC 1 decreased to 12.22 $\mathrm{MT} \mathrm{ha}^{-1}\left(192 \mathrm{bu} \mathrm{ac}^{-1}\right)$, a 1.0\% difference. In the case of the other LCCs, the HWYld increased for LCC 2 from 10.31 MT ha ${ }^{-1}\left(162 \mathrm{bu} \mathrm{ac}^{-1}\right)$ to $10.37 \mathrm{MT} \mathrm{ha}^{-1}\left(163 \mathrm{bu} \mathrm{ac}^{-1}\right)$, 
Table 2. Estimated original and modified hectare-weighted yields (HWYld) and estimated residue removal rates (RR) per land capability classification (LCC) for ten counties in the study area, as well as percent differences between HWYlds and percent of soil hectares without a yield. Original values of HWYlds were calculated using only existing soil yields, whereas modified values took into account soil hectares without a yield after replacing the "no data" yield value for an average LCC yield. HWYlds are in MT ha (bu ac $^{-1}$ ), and estimated residue removal rates are in $\mathrm{kg} \mathrm{ha}^{-1}\left(\mathrm{lbs} \mathrm{ac}{ }^{-1}\right)$ per $\mathrm{LCC}$.

\begin{tabular}{|c|c|c|c|c|c|c|c|c|c|c|}
\hline \multirow[b]{2}{*}{ County and State } & \multicolumn{2}{|c|}{ LCC 1} & \multicolumn{2}{|c|}{ LCC 2} & \multicolumn{2}{|c|}{ LCC 3} & \multicolumn{2}{|c|}{ LCC 4} & \multirow{2}{*}{\multicolumn{2}{|c|}{ County }} \\
\hline & HWYld & RR & HWYld & RR & HWYld & RR & HWYld & RR & & \\
\hline \multicolumn{11}{|l|}{ Original values } \\
\hline Baca, Colo. & $\begin{array}{c}8.65 \\
(136) \\
\end{array}$ & $\begin{array}{c}8,607 \\
(7,574) \\
\end{array}$ & $\begin{array}{r}8.53 \\
(134) \\
\end{array}$ & $\begin{array}{c}8,955 \\
(7,880) \\
\end{array}$ & $\begin{array}{r}8.34 \\
(131) \\
\end{array}$ & $\begin{array}{r}8,697 \\
(7,653) \\
\end{array}$ & $\begin{array}{c}7.95 \\
(125) \\
\end{array}$ & $\begin{array}{c}9,084 \\
(7,994) \\
\end{array}$ & \multicolumn{2}{|c|}{$\begin{array}{c}8.40 \\
(132)\end{array}$} \\
\hline Ford, Kans. & $\begin{array}{l}11.84 \\
(186)\end{array}$ & $\begin{array}{c}11,760 \\
(10,349)\end{array}$ & $\begin{array}{l}11.45 \\
(180) \\
\end{array}$ & $\begin{array}{c}11,883 \\
(10,457)\end{array}$ & $\begin{array}{c}8.72 \\
(137) \\
\end{array}$ & $\begin{array}{c}9,334 \\
(8,214)\end{array}$ & $\begin{array}{c}6.62 \\
(104) \\
\end{array}$ & $\begin{array}{c}7,651 \\
(6,733) \\
\end{array}$ & \multicolumn{2}{|c|}{$\begin{array}{l}11.07 \\
(174) \\
\end{array}$} \\
\hline Greeley, Kans. & $\begin{array}{l}11.39 \\
(179) \\
\end{array}$ & $\begin{array}{c}11,159 \\
(9,820) \\
\end{array}$ & $\begin{array}{c}8.40 \\
(132) \\
\end{array}$ & $\begin{array}{c}9,090 \\
(7,999) \\
\end{array}$ & $\begin{array}{c}7.45 \\
(117) \\
\end{array}$ & $\begin{array}{c}8,130 \\
(7,154) \\
\end{array}$ & $\begin{array}{l}6.05 \\
(95) \\
\end{array}$ & $\begin{array}{c}7,213 \\
(6,347) \\
\end{array}$ & \multicolumn{2}{|c|}{$\begin{array}{l}10.37 \\
(163)\end{array}$} \\
\hline Meade, Kans. & $\begin{array}{l}11.84 \\
(186)\end{array}$ & $\begin{array}{c}12,307 \\
(10,830)\end{array}$ & $\begin{array}{l}10.37 \\
(163) \\
\end{array}$ & $\begin{array}{r}10,826 \\
(9,527)\end{array}$ & $\begin{array}{c}9.67 \\
(152) \\
\end{array}$ & $\begin{array}{c}10,398 \\
(9,150) \\
\end{array}$ & - & - & \multicolumn{2}{|c|}{$\begin{array}{l}11.01 \\
(173)\end{array}$} \\
\hline Stevens, Kans. & $\begin{array}{l}12.35 \\
(194)\end{array}$ & $\begin{array}{c}12,523 \\
(11,020)\end{array}$ & $\begin{array}{l}10.31 \\
(162)\end{array}$ & $\begin{array}{l}10,585 \\
(9,315)\end{array}$ & $\begin{array}{c}8.59 \\
(135)\end{array}$ & $\begin{array}{c}9,185 \\
(8,083)\end{array}$ & $\begin{array}{l}5.09 \\
(80)\end{array}$ & $\begin{array}{c}5,920 \\
(5,210)\end{array}$ & \multicolumn{2}{|c|}{$\begin{array}{l}11.01 \\
(173)\end{array}$} \\
\hline Beaver, Okla. & $\begin{array}{c}9.23 \\
(145) \\
\end{array}$ & $\begin{array}{c}9,411 \\
(8,282)\end{array}$ & $\begin{array}{c}8.53 \\
(134) \\
\end{array}$ & $\begin{array}{c}8,782 \\
(7,728)\end{array}$ & $\begin{array}{l}6.17 \\
(97) \\
\end{array}$ & $\begin{array}{c}6,992 \\
(6,153) \\
\end{array}$ & $\begin{array}{c}7.32 \\
(115) \\
\end{array}$ & $\begin{array}{c}8,241 \\
(7,252)\end{array}$ & \multicolumn{2}{|c|}{$\begin{array}{c}7.89 \\
(124) \\
\end{array}$} \\
\hline Cimarron, Okla. & - & - & $\begin{array}{l}11.71 \\
(184) \\
\end{array}$ & $\begin{array}{c}11,914 \\
(10,484) \\
\end{array}$ & $\begin{array}{l}11.14 \\
(175) \\
\end{array}$ & $\begin{array}{c}12,231 \\
(10,763)\end{array}$ & $\begin{array}{c}6.36 \\
(100) \\
\end{array}$ & $\begin{array}{c}7,211 \\
(6,346) \\
\end{array}$ & \multicolumn{2}{|c|}{$\begin{array}{l}10.63 \\
(167) \\
\end{array}$} \\
\hline Hutchinson, Tex. & - & - & $\begin{array}{l}11.90 \\
(187)\end{array}$ & $\begin{array}{c}11,838 \\
(10,417)\end{array}$ & $\begin{array}{c}9.35 \\
(147)\end{array}$ & $\begin{array}{l}10,128 \\
(8,913)\end{array}$ & - & - & \multicolumn{2}{|c|}{$\begin{array}{l}11.26 \\
(177)\end{array}$} \\
\hline Lipscomb, Tex. & - & - & $\begin{array}{l}11.01 \\
(173) \\
\end{array}$ & $\begin{array}{r}10,924 \\
(9,613) \\
\end{array}$ & $\begin{array}{l}10.18 \\
(160) \\
\end{array}$ & $\begin{array}{r}10,925 \\
(9,614) \\
\end{array}$ & $\begin{array}{c}7.95 \\
(125) \\
\end{array}$ & $\begin{array}{c}8,538 \\
(7,513) \\
\end{array}$ & \multicolumn{2}{|c|}{$\begin{array}{l}10.05 \\
(158) \\
\end{array}$} \\
\hline Roberts, Tex. & $\begin{array}{l}10.18 \\
(160) \\
\end{array}$ & $\begin{array}{r}10,216 \\
(8,990)\end{array}$ & $\begin{array}{l}11.58 \\
(182) \\
\end{array}$ & $\begin{array}{c}11,984 \\
(10,546)\end{array}$ & $\begin{array}{c}9.48 \\
(149) \\
\end{array}$ & $\begin{array}{c}9,611 \\
(8,458)\end{array}$ & $\begin{array}{c}7.06 \\
(111) \\
\end{array}$ & $\begin{array}{c}8,009 \\
(7,048)\end{array}$ & \multicolumn{2}{|c|}{$\begin{array}{l}10.37 \\
(163)\end{array}$} \\
\hline \multicolumn{11}{|l|}{ Modified values } \\
\hline Baca, Colo. & $\begin{array}{c}9.10 \\
(143) \\
\end{array}$ & $\begin{array}{c}9,644 \\
(8,487) \\
\end{array}$ & $\begin{array}{c}8.72 \\
(137) \\
\end{array}$ & $\begin{array}{c}9,488 \\
(8,349) \\
\end{array}$ & $\begin{array}{c}8.27 \\
(130) \\
\end{array}$ & $\begin{array}{c}8,692 \\
(7,649) \\
\end{array}$ & $\begin{array}{r}7.89 \\
(124) \\
\end{array}$ & $\begin{array}{c}9,084 \\
(7,994)\end{array}$ & \multicolumn{2}{|c|}{$\begin{array}{r}8.59 \\
(135) \\
\end{array}$} \\
\hline Ford, Kans. & $\begin{array}{l}11.77 \\
(185) \\
\end{array}$ & $\begin{array}{c}11,760 \\
(10,349) \\
\end{array}$ & $\begin{array}{l}11.33 \\
(178) \\
\end{array}$ & $\begin{array}{c}11,883 \\
(10,457) \\
\end{array}$ & $\begin{array}{r}8.59 \\
(135) \\
\end{array}$ & $\begin{array}{c}9,334 \\
(8,214) \\
\end{array}$ & $\begin{array}{c}6.62 \\
(104) \\
\end{array}$ & $\begin{array}{c}7,651 \\
(6,733) \\
\end{array}$ & \multicolumn{2}{|c|}{$\begin{array}{l}10.88 \\
(171)\end{array}$} \\
\hline Greeley, Kans. & $\begin{array}{l}11.39 \\
(179) \\
\end{array}$ & $\begin{array}{c}11,159 \\
(9,820)\end{array}$ & $\begin{array}{c}8.40 \\
(132) \\
\end{array}$ & $\begin{array}{c}9,090 \\
(7,999)\end{array}$ & $\begin{array}{c}7.45 \\
(117) \\
\end{array}$ & $\begin{array}{c}8,130 \\
(7,154)\end{array}$ & $\begin{array}{l}6.05 \\
(95) \\
\end{array}$ & $\begin{array}{c}7,213 \\
(6,347)\end{array}$ & \multicolumn{2}{|c|}{$\begin{array}{l}10.37 \\
(163) \\
\end{array}$} \\
\hline Meade, Kans. & $\begin{array}{l}11.84 \\
(186) \\
\end{array}$ & $\begin{array}{c}12,307 \\
(10,830) \\
\end{array}$ & $\begin{array}{l}10.37 \\
(163) \\
\end{array}$ & $\begin{array}{r}10,826 \\
(9,527) \\
\end{array}$ & $\begin{array}{c}9.67 \\
(152) \\
\end{array}$ & $\begin{array}{r}10,398 \\
(9,150) \\
\end{array}$ & - & - & \multicolumn{2}{|c|}{$\begin{array}{l}10.95 \\
(172)\end{array}$} \\
\hline Stevens, Kans. & $\begin{array}{l}12.22 \\
(192) \\
\end{array}$ & $\begin{array}{c}12,522 \\
(11,020)\end{array}$ & $\begin{array}{l}10.37 \\
(163) \\
\end{array}$ & $\begin{array}{c}10,585 \\
(9,315)\end{array}$ & $\begin{array}{c}8.59 \\
(135) \\
\end{array}$ & $\begin{array}{c}9,185 \\
(8,083) \\
\end{array}$ & $\begin{array}{l}5.09 \\
(80) \\
\end{array}$ & $\begin{array}{c}5,920 \\
(5,210) \\
\end{array}$ & \multicolumn{2}{|c|}{$(165)$} \\
\hline Beaver, Okla. & $\begin{array}{c}9.23 \\
(145) \\
\end{array}$ & $\begin{array}{c}9,411 \\
(8,282)\end{array}$ & $\begin{array}{c}8.59 \\
(135) \\
\end{array}$ & $\begin{array}{c}8,782 \\
(7,728) \\
\end{array}$ & $\begin{array}{l}6.11 \\
(96) \\
\end{array}$ & $\begin{array}{c}6,990 \\
(6,151) \\
\end{array}$ & $\begin{array}{c}7.32 \\
(115) \\
\end{array}$ & $\begin{array}{c}8,241 \\
(7,252)\end{array}$ & \multicolumn{2}{|c|}{$\begin{array}{c}7.38 \\
(116)\end{array}$} \\
\hline Cimarron, Okla. & - & - & $\begin{array}{l}11.45 \\
(180) \\
\end{array}$ & $\begin{array}{c}11,914 \\
(10,484) \\
\end{array}$ & $\begin{array}{l}11.14 \\
(175) \\
\end{array}$ & $\begin{array}{c}12,231 \\
(10,763)\end{array}$ & $\begin{array}{c}6.36 \\
(100) \\
\end{array}$ & $\begin{array}{c}7,211 \\
(6,346) \\
\end{array}$ & & \\
\hline Hutchinson, Tex. & - & - & $\begin{array}{l}11.84 \\
(186) \\
\end{array}$ & $\begin{array}{c}11,838 \\
(10,417)\end{array}$ & $\begin{array}{c}9.48 \\
(149) \\
\end{array}$ & $\begin{array}{c}10,128 \\
(8,913) \\
\end{array}$ & - & - & & \\
\hline Lipscomb, Tex. & - & - & $\begin{array}{l}10.82 \\
(170) \\
\end{array}$ & $\begin{array}{c}11,590 \\
(10,199) \\
\end{array}$ & $\begin{array}{l}10.18 \\
(160) \\
\end{array}$ & $\begin{array}{r}10,925 \\
(9,614) \\
\end{array}$ & $\begin{array}{c}7.95 \\
(125) \\
\end{array}$ & $\begin{array}{c}8,538 \\
(7,513) \\
\end{array}$ & & \\
\hline Roberts, Tex. & $\begin{array}{l}10.18 \\
(160) \\
\end{array}$ & $\begin{array}{c}10,216 \\
(8,990)\end{array}$ & $\begin{array}{l}11.33 \\
(178) \\
\end{array}$ & $\begin{array}{c}11,984 \\
(10,546) \\
\end{array}$ & $\begin{array}{c}9.48 \\
(149) \\
\end{array}$ & $\begin{array}{c}9,611 \\
(8,458) \\
\end{array}$ & $\begin{array}{c}7.19 \\
(113) \\
\end{array}$ & $\begin{array}{c}8,009 \\
(7,048) \\
\end{array}$ & & \\
\hline Percent difference betw & IWYIds a & ad percent & oil hectare & S without & & & & & & \\
\hline & $\begin{array}{c}\text { Diff. } \\
\text { between } \\
\text { HWYld } \\
\text { values }\end{array}$ & $\begin{array}{c}\text { Soil ha } \\
\text { with no } \\
\text { yield } \\
\text { values }\end{array}$ & $\begin{array}{c}\text { Diff. } \\
\text { between } \\
\text { HWYld } \\
\text { values }\end{array}$ & $\begin{array}{c}\text { Soil ha } \\
\text { with no } \\
\text { yield } \\
\text { values }\end{array}$ & $\begin{array}{c}\text { Diff. } \\
\text { between } \\
\text { HWYld } \\
\text { values }\end{array}$ & $\begin{array}{c}\text { Soil ha } \\
\text { with no } \\
\text { yield } \\
\text { values }\end{array}$ & $\begin{array}{c}\text { Diff. } \\
\text { between } \\
\text { HWYld } \\
\text { values }\end{array}$ & $\begin{array}{c}\text { Soil ha } \\
\text { with no } \\
\text { yield } \\
\text { values }\end{array}$ & $\begin{array}{c}\text { Diff. } \\
\text { between } \\
\text { HWYld } \\
\text { values }\end{array}$ & $\begin{array}{c}\text { Soil ha } \\
\text { with no } \\
\text { yield } \\
\text { values }\end{array}$ \\
\hline Baca, Colo. & 5.1 & 55.5 & 2.2 & 48.4 & 0.8 & 20.3 & 0.8 & 38.8 & 2.3 & 40.7 \\
\hline Ford, Kans. & 0.5 & 4.2 & 1.1 & 7.2 & 1.5 & 13.3 & 0.0 & 19.8 & 1.7 & 7.2 \\
\hline Greeley, Kans. & 0.0 & 0.0 & 0.0 & 0.0 & 0.0 & 0.0 & 0.0 & 0.0 & 0.0 & 0.0 \\
\hline Meade, Kans. & 0.0 & 0.0 & 0.0 & 1.6 & 0.0 & 38.8 & - & - & 0.6 & 7.1 \\
\hline Stevens, Kans. & 1.0 & 13.7 & 0.6 & 10.1 & 0.0 & 99.9 & 0.0 & 65.1 & 4.6 & 27.5 \\
\hline Beaver, Okla. & 0.0 & 0.0 & 0.7 & 16.0 & 1.0 & 66.3 & 0.0 & 72.6 & 6.5 & 43.8 \\
\hline Cimarron, Okla. & - & - & 2.2 & 35.1 & 0.0 & 99.2 & 0.0 & 59.4 & 1.2 & 67.9 \\
\hline Hutchinson, Tex. & - & - & 0.5 & 5.8 & 1.4 & 45.6 & - & 100.0 & 8.5 & 31.9 \\
\hline Lipscomb, Tex. & - & 100.0 & 1.7 & 39.7 & 0.0 & 32.2 & 0.0 & 90.1 & 9.5 & 64.0 \\
\hline Roberts, Tex. & 0.0 & 43.5 & 2.2 & 22.7 & 0.0 & 10.8 & 1.8 & 95.2 & 17.8 & 64.5 \\
\hline
\end{tabular}

a $0.6 \%$ difference, and remained unchanged for LCC 3 (8.59 $\left.\mathrm{MT} \mathrm{ha}^{-1} ; 135 \mathrm{bu} \mathrm{ac}^{-1}\right)$ and LCC 4 (5.09 $\mathrm{MT} \mathrm{ha}^{-1}$; $\left.80 \mathrm{bu} \mathrm{ac}^{-1}\right)$. The HWYlds remained the same for LCC 3 and 4 because the existing soil yields were all the same value; because existing soils are used to calculate the average LCC yield, the HWYlds remained the same. Interestingly, even though there was a percent difference in LCC 1 and 2, the estimated LCC residue removal rates remained the same.

The third part of table 2 shows the percent difference between the original and modified HWYlds and the percent of soil hectares without a yield per LCC. For Stevens 
County, it was observed that $13.7 \%(9,407$ ha; 23,245 ac $)$ of the total LCC 1 soil hectares had missing yields. LCC 2 had 10.1\% (9,691 ha; 23,947 ac), LCC 3 had 99.9\% (31,371 ha; 77,519 ac), and LCC 4 had 65.1\% (5,993 ha; $14,809 \mathrm{ac}$ ) of the total LCC soil hectares without a yield. In total, $27.5 \%(56,462 \mathrm{ha} ; 139,520 \mathrm{ac})$ of the county soil hectares classified LCC 1, 2, 3, and 4 were missing yield values.

A separate analysis was undertaken to calculate the percent soil hectares without a yield per county. It was observed that on average, $21.8 \%$ of county hectares were missing a yield value, with the minimum being $0.0 \%$ (Greeley, Kans.) and the maximum 67.9\% (Cimarron, Okla.). Texas had on average the highest percentage of soil hectares without a yield (37.4\%), followed by Oklahoma (36.3\%), Colorado (27.9\%), and Kansas (10.3\%). In order to determine at what level of missing yield values the modified HWYld should be calculated, the number of counties with soil hectares missing yield values was quantified. A lower limit was set, and then the number of counties was counted for which the percentage of soil hectares missing yield exceeded the established limit. The lower limit of $25 \%$ was increased to $50 \%$ in increments of five percentage points. Fifteen counties out of the 31 in the study area (i.e., $48 \%$ ) had $25 \%$ of their hectares missing yield values, decreasing to ten $(32 \%)$, six $(19 \%)$, five $(16 \%)$, three $(10 \%)$, and three $(10 \%)$ counties having hectares missing a yield, respectively. Given that the greatest decrease in number of counties missing yield values was observed between limits of $25 \%$ and $35 \%$, it was concluded that setting the lower limit at $35 \%$ would be best for our case study.

Given that estimation of LCC HWYlds is dependent on existing SSURGO yields, we determined that it is advisable to verify acquired SSURGO yield data before using them. If more than $20 \%$ of the study area counties have more than $35 \%$ of their soil hectares without a yield value, then calculating modified HWYld values will offer a more accurate representation of a county's LCC HWYlds, which is used to predict residue removal rates.

\section{IMPROVEMENTS TO THE GIS-BASED METHOD}

Table 3 shows estimated residue availability per $16 \mathrm{~km}$ (10 mi) service area from plant location (Hugoton, Kans.) for five plant capacities $(151,227,378,567$, and 757 MLY; 40, 60, 100, 150, and $200 \mathrm{MGY}$ ) and estimated annual feedstock requirements using both GIS-based methods. The first part of table 3 shows residue availability per $16 \mathrm{~km}$ (10 mi) service area using the constant rate removal (CRR) method. In the case of a plant with a 151 MLY (40 MGY) capacity and $100 \%$ residue removal, the first service area ( 0 to $16 \mathrm{~km}$; 0 to $10 \mathrm{mi}$ ) was estimated to provide $13.7 \%$ of the annual feedstock requirements, while the second (16 to $32 \mathrm{~km} ; 10$ to $20 \mathrm{mi}$ ) and third (32 to $48 \mathrm{~km} ; 20$ to $30 \mathrm{mi}$ ) service areas would provide $45.1 \%$ and $41.2 \%$, respectively. Accordingly, a plant with a 151 MLY (40 MGY) capacity would meet its annual feedstock requirements within the third service area ( 32 to $48 \mathrm{~km} ; 20$ to $30 \mathrm{mi}$ ). In the case of other plant capacities (227, 378, 567, and 757 MLY; 60, 100,150 , and $200 \mathrm{MGY}$ ), the total annual feedstock requirements would be met in the fourth (48 to $64 \mathrm{~km} ; 30$ to $40 \mathrm{mi}$ ), sixth ( 80 to $96 \mathrm{~km} ; 50$ to $60 \mathrm{mi}$ ), seventh (96 to $112 \mathrm{~km}$; 60 to $70 \mathrm{mi}$ ), and ninth $(128$ to $144 \mathrm{~km} ; 80$ to $90 \mathrm{mi}$ ) service areas, respectively.

The second part of table 3 shows the residue availability

Table 3. Estimated hectares and residue availability per $16 \mathrm{~km}(10 \mathrm{mi})$ service area from plant location (Hugoton, Kans.) for five plant capacities using the constant removal rate (CRR) and variable residue removal (VRR) GIS-based methods and estimated annual feedstock requirements using a corn biomass yield of $272.5 \mathrm{~L} \mathrm{DT}^{-1}\left(72 \mathrm{gal} \mathrm{DT}^{-1}\right) .^{[\mathrm{a}]}$

\begin{tabular}{|c|c|c|c|c|c|c|c|c|c|c|c|c|}
\hline \multirow[b]{4}{*}{$\begin{array}{c}\text { Plant } \\
\text { Capacity }\end{array}$} & \multirow{4}{*}{$\begin{array}{c}\text { Annual } \\
\text { Feedstock } \\
\text { Required }\end{array}$} & \multicolumn{10}{|c|}{ Service Area in $\mathrm{km}(\mathrm{mi})$} & \multirow[b]{4}{*}{$\begin{array}{c}\text { Total } \\
(\%)\end{array}$} \\
\hline & & $\begin{array}{c}0-16 \\
(0-10)\end{array}$ & $\begin{array}{c}16-32 \\
(10-20)\end{array}$ & $\begin{array}{c}32-48 \\
(20-30)\end{array}$ & $\begin{array}{c}48-64 \\
(30-40)\end{array}$ & $\begin{array}{c}64-80 \\
(40-50)\end{array}$ & $\begin{array}{c}80-96 \\
(50-60)\end{array}$ & $\begin{array}{l}96-112 \\
(60-70)\end{array}$ & $\begin{array}{l}112-128 \\
(70-80)\end{array}$ & $\begin{array}{l}128-144 \\
(80-90)\end{array}$ & $\begin{array}{l}144-160 \\
(90-100)\end{array}$ & \\
\hline & & \multicolumn{10}{|c|}{ Hectares (acres) Available per Service Area } & \\
\hline & & $\begin{array}{c}10,268 \\
(25,372)\end{array}$ & $\begin{array}{c}33,821 \\
(83,574)\end{array}$ & $\begin{array}{c}31,572 \\
(78,017)\end{array}$ & $\begin{array}{c}44,298 \\
(109,462)\end{array}$ & $\begin{array}{c}46,290 \\
(114,385)\end{array}$ & $\begin{array}{c}62,350 \\
(154,071)\end{array}$ & $\begin{array}{c}56,696 \\
(140,100)\end{array}$ & $\begin{array}{c}50,378 \\
(124,486)\end{array}$ & $\begin{array}{c}45,548 \\
(112,551)\end{array}$ & $\begin{array}{c}37,388 \\
(92,387)\end{array}$ & \\
\hline \multirow{2}{*}{\multicolumn{2}{|c|}{ CRR method }} & \multicolumn{10}{|c|}{ Residue available per service area (dry tons) using intensive tillage practices by removing $100 \%$} & \\
\hline & & 76,116 & 250,722 & 234,050 & 328,386 & 343,155 & 462,213 & 420,301 & 373,459 & 337,653 & 227,162 & \\
\hline $151(40)$ & 555,556 & 13.7 & 45.1 & 41.2 & - & - & - & - & - & - & - & 100 \\
\hline $227(60)$ & 833,333 & 9.1 & 30.1 & 28.1 & 32.7 & - & - & - & - & - & - & 100 \\
\hline $378(100)$ & $1,388,889$ & 5.5 & 18.1 & 16.9 & 23.6 & 24.7 & 11.3 & - & - & - & - & 100 \\
\hline $567(150)$ & $2,083,333$ & 3.7 & 12.0 & 11.2 & 15.8 & 16.5 & 22.2 & 18.7 & - & - & - & 100 \\
\hline $757(200)$ & $2,777,778$ & 2.7 & 9.0 & 8.4 & 11.8 & 12.4 & 16.6 & 15.1 & 13.4 & 10.4 & - & 100 \\
\hline \multirow{2}{*}{\multicolumn{2}{|c|}{ VRR method }} & \multicolumn{10}{|c|}{ Residue available per service area (dry tons) using intensive tillage practices by removing $100 \%$} & \\
\hline & & 109,381 & 357,782 & 300,646 & 453,468 & 472,214 & 633,969 & 532,763 & 495,015 & 481,460 & 400,359 & \\
\hline $151(40)$ & 555,556 & 19.7 & 64.4 & 15.9 & - & - & - & - & - & - & - & 100 \\
\hline $227(60)$ & 833,333 & 13.1 & 42.9 & 36.1 & 7.9 & - & - & - & - & - & - & 100 \\
\hline $378(100)$ & $1,388,889$ & 7.9 & 25.8 & 21.6 & 32.6 & 12.1 & - & - & - & - & - & 100 \\
\hline $567(150)$ & $2,083,333$ & 5.3 & 17.2 & 14.4 & 21.8 & 22.7 & 18.7 & - & - & - & - & 100 \\
\hline $757(200)$ & $2,777,778$ & 3.9 & 12.9 & 10.8 & 16.3 & 17.0 & 22.8 & 16.2 & - & - & - & 100 \\
\hline \multirow{2}{*}{\multicolumn{2}{|c|}{ VRR method }} & \multicolumn{10}{|c|}{$\begin{array}{l}\text { Residue available per service area (dry tons) using conservation tillage practices } \\
\text { with at least } 30 \% \text { soil coverage at second year of planting }\end{array}$} & \\
\hline & & 77,198 & 253,877 & 205,024 & 326,007 & 337,960 & 457,547 & 352,378 & 346,109 & 335,562 & 275,824 & \\
\hline $151(40)$ & 555,556 & 13.9 & 45.7 & 36.9 & 3.5 & - & - & - & - & - & - & 100 \\
\hline $227(60)$ & 833,333 & 9.3 & 30.5 & 24.6 & 35.7 & - & - & - & - & - & - & 100 \\
\hline $378(100)$ & $1,388,889$ & 5.6 & 18.3 & 14.8 & 23.5 & 24.3 & 13.6 & - & - & - & - & 100 \\
\hline $567(150)$ & $2,083,333$ & 3.7 & 12.2 & 9.8 & 15.6 & 16.2 & 22.0 & 16.9 & 3.5 & - & - & 100 \\
\hline $757(200)$ & $2,777,778$ & 2.8 & 9.1 & 7.4 & 11.7 & 12.2 & 16.5 & 12.7 & 12.5 & 12.1 & 3.1 & 100 \\
\hline
\end{tabular}

[a] Plant capacity is in million liters per year (million gallons per year), and annual feedstock required is in dry tons per year. 
per $16 \mathrm{~km}(10 \mathrm{mi})$ service area using the variable rate removal (VRR) method using intensive tillage by removing $100 \%$ of the residue. The supply area for lower-capacity plants (151 and 227 MLY; 40 and $60 \mathrm{MGY}$ ) remained the same, while it decreased (i.e., $16 \mathrm{~km} ; 10 \mathrm{mi}$ ) for highercapacity plants $(378,567$, and 757 MLY; 100, 150, and $200 \mathrm{MGY}$ ) due to an increase in residue availability per service area. In the case of the $151 \mathrm{MLY}$ (40 MGY) plant, the first service area ( 0 to $16 \mathrm{~km}$; 0 to $10 \mathrm{mi})$ provided roughly the same annual feedstock requirement (19.7\%) as the CRR method. However, an increase of 107,060 DT of residue in the second service area (16 to $32 \mathrm{~km} ; 10$ to $20 \mathrm{mi}$ ) increased the service area's supply capability to $64.4 \%$. The third service area (32 to $48 \mathrm{~km} ; 20$ to $30 \mathrm{mi}$ ) provided the remaining $15.9 \%$ of residue needed to meet the annual feedstock requirement. The total annual feedstock requirements for the other capacity plants $(227,378$, 567, and 757 MLY; 60, 100, 150, and $200 \mathrm{MGY}$ ) would be met in the fourth (48 to $64 \mathrm{~km} ; 30$ to $40 \mathrm{mi}$ ), fifth (64 to $80 \mathrm{~km}$; 40 to $50 \mathrm{mi}$ ), sixth ( 80 to $96 \mathrm{~km} ; 50$ to $60 \mathrm{mi}$ ), and seventh (96 to $112 \mathrm{~km} ; 60$ to $70 \mathrm{mi}$ ) service areas, respectively.

When comparing both methods using intensive tillage by removing $100 \%$ of the residue, table 3 shows that even though hectare availability is the same for each service area, the VRR method estimated on average $113,384 \pm 38,770$ DT more residue available per service area compared to the CRR method. This difference in residue availability was attributed to the use of soil characteristics, field-level yield, and field management when estimating residue removal rates, instead of using a constant removal rate of 7.4 DT ha ${ }^{-1}\left(3 \mathrm{DT} \mathrm{ac}^{-1}\right)$. The residue removal rates within the study area averaged 9.4 $\pm 1.7 \mathrm{DT} \mathrm{ha}^{-1}\left(3.8 \pm 0.7 \mathrm{DT} \mathrm{ac}^{-1}\right)$, with a 5.7 to $13.3 \mathrm{DT} \mathrm{ha}^{-1}$ (2.3 to $\left.5.4 \mathrm{DT} \mathrm{ac}^{-1}\right)$ range.

In the case of Stevens County, its average residue removal rate was $9.4 \pm 2.2 \mathrm{DT} \mathrm{ha}^{-1}\left(3.8 \pm 0.9 \mathrm{DT} \mathrm{ac}^{-1}\right)$, with a 5.9 to $12.3 \mathrm{DT} \mathrm{ha}^{-1}$ (2.4 to $5.0 \mathrm{DT} \mathrm{ac}^{-1}$ ) range (fig. 3). Even though Stevens County had one of the lowest residue removal rates (i.e., 5.9 DT ha ${ }^{-1}$; $2.4 \mathrm{DT} \mathrm{ac}^{-1}$ ) among its hectares, this residue removal rate only applied to $0.1 \%$ of the total county hectares (45,857 ha; 111,314 acres). The three predominant residue removal rates in Stevens County were 9.1, 10.4, and 12.3 DT ha ${ }^{-1}\left(3.7,4.2\right.$, and 5.0 DT ac ${ }^{-1}$ ), which relate to $8.1 \%, 53.8 \%$, and $35.8 \%$ of the county's total hectares, respectively. These high residue removal rates can be attributed to Stevens County's high corn yields and good-quality soil characteristics. Even though higher residue removal rates can be achieved using intensive tillage by removing $100 \%$ of the residue, this is not a recommended practice because it can lead to erosion problems and loss in soil productivity due to the lack of nutrient cycling, among other factors. Therefore, it is advisable to use conservation tillage, which is a soil cultivation method that leaves the previous year's crop residue on the field before and after planting the next crop to reduce soil erosion and runoff, and improve soil productivity. To provide these conservation benefits, at least $30 \%$ of the soil surface must be covered with residue after planting the next crop.

The effect of conservation tillage on the amount available for removal was also simulated. The third part of table 3 shows residue availability per $16 \mathrm{~km}(10 \mathrm{mi})$ service area for the VRR method using conservation tillage practices. When comparing this scenario to the CRR method using intensive tillage, differences in residue availability per service area were observed for all service areas for all five plant capacities. On average, there was a 13,573 $\pm 22,195$ DT decrease in the predicted amount of residue available per service area. As a result, the average residue removal rate in the study area decreased to $5.9 \pm 2.2 \mathrm{DT} \mathrm{ha}^{-1}$ $\left(2.4 \pm 0.9 \mathrm{DT} \mathrm{ac}^{-1}\right)$, with a 2.5 to $9.6 \mathrm{DT} \mathrm{ha}^{-1}(1.0$ to $3.9 \mathrm{DT}$ $\mathrm{ac}^{-1}$ ) range.

This slight decrease in average residue availability per service area increased the number of total service areas needed to meet the annual feedstock requirements by one service area for 151, 567, and 757 MLY (40, 150, and 200 MGY) plant capacities, yet remained the same for 227 and 378 MLY (60 and $100 \mathrm{MGY}$ ) plant capacities. It is important to note that only $3.5 \%$ or less of the total annual feedstock requirements was provided by these additional service areas. Therefore, the VRR method required practi-
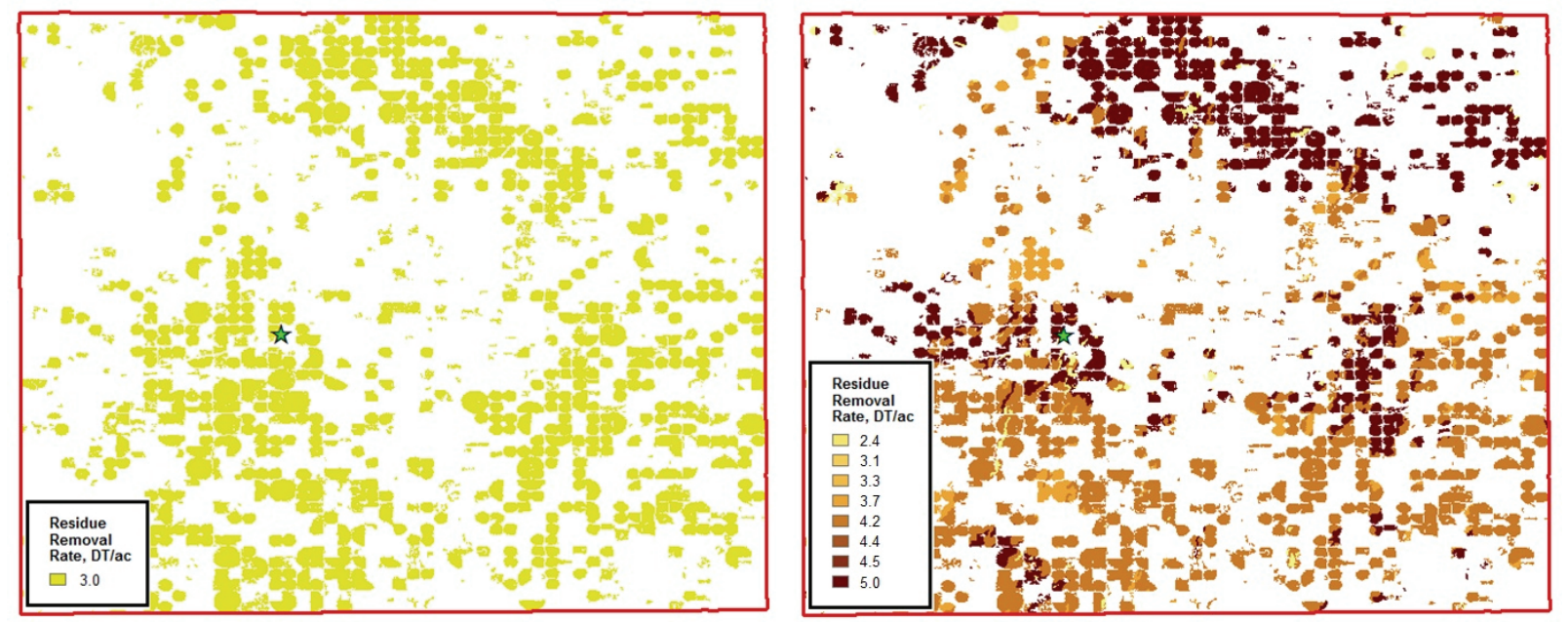

Figure 3. Estimated residue removal rates for Stevens County, Kansas, using the constant removal rate (CRR) and variable residue removal (VRR) methods based on intensive tillage practices by removing $100 \%$ of residue available. 
Table 4. Effect of yield and soil type on residue availability in Stevens County using the same field management for all scenarios. ${ }^{[a]}$

\begin{tabular}{|c|c|c|c|c|}
\hline \multirow[b]{2}{*}{ Yield } & \multicolumn{4}{|c|}{ Residue Availability } \\
\hline & $\begin{array}{c}\text { LCC } 1 \\
\text { (5210 Belfon) }\end{array}$ & $\begin{array}{c}\text { LCC } 2 \\
\text { (5220 Dalhart) }\end{array}$ & $\begin{array}{c}\text { LCC } 3 \\
(5236 \text { Eva) }\end{array}$ & $\begin{array}{c}\text { LCC } 4 \\
\text { (5236 Optima) }\end{array}$ \\
\hline $\begin{array}{l}12.22 \\
(192)\end{array}$ & $\begin{array}{c}9,643 \\
(8,486)\end{array}$ & $\begin{array}{c}9,241 \\
(8,132)\end{array}$ & $\begin{array}{c}9,375 \\
(8,250)\end{array}$ & $\begin{array}{c}9,264 \\
(8,152)\end{array}$ \\
\hline $\begin{array}{l}10.37 \\
(163)\end{array}$ & $\begin{array}{c}7,681 \\
(6,759)\end{array}$ & $\begin{array}{c}7,376 \\
(6,491)\end{array}$ & $\begin{array}{c}7,061 \\
(6,214)\end{array}$ & $\begin{array}{c}7,163 \\
(6,303)\end{array}$ \\
\hline $\begin{array}{l}8.59 \\
(135)\end{array}$ & $\begin{array}{c}4,367 \\
(3,843)\end{array}$ & $\begin{array}{c}4,597 \\
(4,045)\end{array}$ & $\begin{array}{c}4,442 \\
(3,909)\end{array}$ & $\begin{array}{c}4,436 \\
(3,904)\end{array}$ \\
\hline $\begin{array}{l}5.09 \\
(80)\end{array}$ & $\begin{array}{c}2,403 \\
(2,115)\end{array}$ & $\begin{array}{c}2,315 \\
(2,037)\end{array}$ & $\begin{array}{c}2,338 \\
(2,057)\end{array}$ & $\begin{array}{c}2,383 \\
(2,097)\end{array}$ \\
\hline & & $\left.\mathrm{bu} \mathrm{ac}^{-1}\right)$ & ted re & abil \\
\hline
\end{tabular}

cally the same number of service areas as the CRR method to procure total annual feedstock requirement, thus making it the preferred approach.

Sustainability is achieved by the use of two improvement parameters in the VRR method. Rather than using a constant removal rate of 7.4 DT ha ${ }^{-1}\left(3 \mathrm{DT} \mathrm{ac}^{-1}\right)$ and intensive tillage where $100 \%$ of the residue is removed, the VRR method predicts residue availability as a function of yield and soil variability. Table 4 shows a matrix of how residue availability is affected by yield and soil type as field management (table 1) remains the same throughout. It can be observed that as yield and soil quality decrease, residue availability decreases. Of these two variables, yield was observed to have a greater effect. It is important to note that in some of the scenarios, the lower-quality soil resulted in higher residue availability. This was a result of higher average yields simulated by WEPS compared to the target yield. For example, the target input yield for LCC 3 was 8.59 $\mathrm{MT} \mathrm{ha}^{-1}\left(135 \mathrm{bu} \mathrm{ac}^{-1}\right)$. The WEPS simulation predicted an average yield of $8.40 \mathrm{MT} \mathrm{ha}^{-1}\left(132 \mathrm{bu} \mathrm{ac}^{-1}\right)$ for Y3-S1, 8.91 MT ha $\mathrm{MT}^{-1}\left(140 \mathrm{bu} \mathrm{ac}^{-1}\right)$ for Y3-S2, and 8.53 $\mathrm{MT} \mathrm{ha}^{-1}$ $\left(134 \mathrm{bu} \mathrm{ac}^{-1}\right)$ for both Y3-S3 and Y3-S4.

\section{VALIDATION OF HECTARE-WEIGHTED YIELDS}

The USDA-NASS provides national, state, and county crop estimates. Producers, agricultural organizations, trade groups, financial institutions, and other entities rely on NASS yield estimates for decision making. Decisions such as planting and marketing, pricing commodities, storing, and crop insurance are made based on NASS yield estimates. National and state estimates are known to be more statistically sound than county-level estimates, mainly because of the limited number of responses. According to NASS guidelines, in cases where there are fewer than 30 responses from an individual county, an estimate for combined counties is published. Nevertheless, a recent report by the USDA Office of Inspector General (OIG) concluded that the current NASS methodology for estimating county yields provides reasonably accurate and reliable information (USDA, 2011b). According to this report, about $20 \%$ of NASS county estimated corn yields differed from Risk Management Agency (RMA) corn yield estimates by more than $\pm 10 \%$ for 346 counties from 2006 to 2008. Having good county yield estimates helps agencies such as the RMA and the FSA to cross-check county-level estimates to determine program benefits. This is important for them because over- or underestimating yields will affect how much crop insurance indemnity is needed. For reference, the RMA's county-average crop insurance indemnities totaled nearly \$1.1 billion from 2007 to 2009 .

In our case study, county HWYlds were validated against the NASS irrigated corn yield averages. Prior to this validation, acquired NASS yield estimates were crosschecked against seven-year FSA irrigated corn yield estimates. The data showed that only $3 \%$ ( 1 out of 31 ) of the counties of NASS irrigated corn yield estimates differed from FSA irrigated corn yield estimates by greater than $\pm 10 \%$. This corroborates conclusions reached by the USDA OIG in its 2011 report. After the NASS yield estimates were cross-checked, they were used to validate county HWYlds. Validation of county HWYlds at the same percent difference (i.e., no greater than $\pm 10 \%$ ) showed that $35 \%$ (11 out of 31 ) of the counties fell outside the established yield estimate difference range. It was concluded that the percent difference fell outside the established range due to the small sample size in our study area (31 counties).

\section{Conclusions}

The results of this case study emphasize the importance of using two additional parameters (i.e., field-level yields and residue removal rates) to further improve the quantification of feedstock availability to supply a biorefinery. Residue removal was maximized based on location, yield, soil characteristics, and field management without causing soil erosion and while maintaining soil productivity. The following are specific conclusions reached from this study:

- If more than $20 \%$ of the study area counties have more than $35 \%$ of their soil hectares without a yield value, then calculating modified HWYld values will offer a more accurate representation of a county's LCC HWYlds, which is used to predict residue removal rates.

- The use of field-level yield estimates based on soil characteristics and the use of variable residue removal estimates based on location, soil characteristics, crop yield, and field management gives the user of the VRR method a sustainable approach to determining how much residue could potentially be removed without causing soil erosion and/or affecting soil productivity in the years to come.

- When using intensive tillage practices by removing $100 \%$ of the crop residue available, the VRR method predicted on average 113,384 DT of additional residue for harvest compared to the CRR method. This increase in residue availability resulted in a higher removal rate $\left(9.4 \pm 1.7 \mathrm{DT} \mathrm{ha}^{-1}, 3.8 \pm 0.7 \mathrm{DT} \mathrm{ac}^{-1}\right.$ average; 5.7 to $13.3 \mathrm{DT} \mathrm{ha}^{-1}, 2.3$ to $5.4 \mathrm{DT} \mathrm{ac}^{-1}$ range) in the study area compared to the constant rate (7.4 DT ha ${ }^{-1}, 3$ DT ac ${ }^{-1}$ ) used by the CRR method.

- Intensive tillage practices are not recommended because they can lead to erosion problems and loss in soil productivity. Conservation tillage practices will help offset these negative effects and are thus rec- 
ommended instead. Conservation benefits are provided when at least $30 \%$ of the soil surface is covered with residue after planting the next crop.

- When using conservation tillage practices, the VRR method estimated on average 13,373 DT less per service area than the CRR method using intensive tillage with $100 \%$ residue removal. Even though this created the need for additional service areas for some plant capacities, these service areas would only supply $3.5 \%$ or less of the total annual feedstock requirements. Therefore, the procurement area was considered practically the same for the VRR method using conservation tillage and the CRR method using intensive tillage with $100 \%$ removal. Consequently, the VRR method turned out to be a more sustainable approach in the quantification of biomass feedstock availability.

\section{ACKNOWLEDGEMENTS}

The authors would like to acknowledge Dr. John Takarto (USDA-ARS Northern Plains Area) and Dr. Richard Nelson (KSU Center for Sustainable Energy) for their assistance with the WEPS simulations. Contribution no. 14340-J from the Kansas Agricultural Experiment Station.

\section{REFERENCES}

Cundiff, S. J., Grisso, R. D., \& Ravula, P. P. (2004). Management system for biomass delivery at a plant conversion. ASAE Paper No. 046169. St. Joseph, Mich.: ASAE.

De Mol, R. M., Jogems, M. A., Beek, P. V., \& Gigler, J. K. (1997). Simulation and optimization of the logistics of biomass fuel collection. Netherlands J. Agric. Sci., 45(1), 217-228.

Gupta, S. C., Onstand, C. A., \& Larson, W. E. (1979). Effects of Tillage and Crop Residue Removal on Erosion, Runoff, and Plant Nutrients. Special Publication No. 25. Ankeny, Iowa: Soil Conservation Society of America.

Krishnakumar, P., \& Ileleji, K. E. (2010). A comparative analysis of the economics and logistics requirements of different biomass feedstock types and forms for ethanol production. Appl. Eng. Agric., 26(5), 899-907. http://dx.doi.org/10.13031/2013.41332.

Martinez, A., \& Maier, D. E. (2011). Quantifying feedstock availability using a geographical information system. Biol. Eng Trans., 4(3), 133-146. http://dx.doi.org/10.13031/2013.39814.
Mukunda, A., Ileleji, K. E., \& Wan, H. (2006). Simulation of corn stover logistics from on-farm storage to an ethanol plant. ASABE Paper No. 066177. St. Joseph, Mich.: ASABE.

Nelson, R. G. (2002). Resources assessment and removal analysis for corn stover and wheat straw in the eastern and midwestern United States: Rainfall and wind-induced soil erosion methodology. Biomass and Bioenergy, 22(5), 349-363. http://dx.doi.org/10.1016/S0961-9534(02)00006-5.

Perlack, R. D., \& Turhollow, A. F. (2003). Feedstock cost analysis of corn stover residues for further processing. Energy, 28(14), 1395-1403. http://dx.doi.org/10.1016/S0360-5442(03)00123-3.

Ravula, P. P., Cundiff, S. J., \& Grisso, R. D. (2003). Cotton logistics as a model for analysis of biomass transportation issues. ASAE Paper No. 036082. St. Joseph, Mich.: ASAE.

Sokhansanj, S., Turhollow, A., \& Perlack, R. (2002). Stochastic modeling of costs of corn stover delivered to an intermediate storage facility. ASAE Paper No. 024190. St. Joseph, Mich.: ASAE.

USDA. (2002). 2002 Census of Agriculture. Washington, D.C.: USDA National Agricultural Statistics Service. Retrieved from www.agcensus.usda.gov/Publications/2002/index.php.

USDA. (2003). Roadmap for agricultural biomass feedstock supply in the United States. Washington, D.C.: U.S. Department of Energy, Energy Efficiency and Renewable Energy. Retrieved from http://feedstockreview.ornl.gov/pdf/hess/roadmap_for_ag biomass feedstock supply in us.pdf.

USDA. (2007). Soil erosion on cropland 2007. Washington, D.C.: USDA National Agricultural Statistics Service. Retrieved from www.nrcs.usda.gov/wps/portal/nrcs/detail/national/technical/nra $/$ nri/?cid=stelprdb1041887.

USDA. (2010). Agriculture Geospatial Data Gateway. Washington, D.C.: USDA Natural Resources Conservation Service. Retrieved from http://datagateway.nrcs.usda.gov.

USDA. (2011a). Soil Data Viewer. Ver. 6.0. Washington, D.C.: USDA Natural Resources Conservation Service. Retrieved from www.nrcs.usda.gov/wps/portal/nrcs/detail/soils/survey/geo/?cid $=$ nrcs $142 \mathrm{p} 2053618$.

USDA. (2011b). National Agricultural Statistics Service: Establishment of average yields. Washington, D.C.: USDA Natural Resources Conservation Service. Retrieved from www.usda.gov/oig/webdocs/50601-0015-KC.pdf.

USDA. (2012a). Wind erosion research. Manhattan, Kans.: USDAARS Wind Erosion Research Unit. Retrieved from www.weru.ksu.edu.

USDA. (2012b). Soil Survey Geographic (SSURGO) database. Washington, D.C.: USDA Natural Resources Conservation Service. Retrieved from http://websoilsurvey.sc.egov.usda.gov/App/HomePage.htm. 